\title{
The use of micronutrient fertilizers in the cultivation of winter wheat
}

\author{
Ivan Gureev ${ }^{1}$ \\ ${ }^{1}$ Federal State Budgetary Scientific Institution "Kursk Federal Agricultural Research Center", Russia
}

\begin{abstract}
The aim of the research was to improve the technology for the production of winter wheat in Central Chernozem Region (CChR) by increasing the efficiency of the application of modern micronutrient fertilizers in conjunction with seed disinfectants and foliar dressing. To achieve this goal, the representative of FSBSI Kursk Federal Agricultural Research Center with the participation of specialists of Central Chernozem Machine Testing Station developed a technology and conducted field experiments on slightly leached medium loamy chernozem with $\mathrm{pH}_{\mathrm{KCl}}=5.1$ and humus content of $5.0 \%$. For the first time on a scientific basis, a significant reserve for saving fertilizer resources has been realized through the use of synergy of interaction between nutrients. For this, the nomenclature and the ratio of the components of the nutritional mixture for foliar applications were established by an innovative method of functional foliar diagnostics using the Aquadonis device. Micronutrient fertilizer Aquamix ST (100 g/t) was applied to the seeds together with various seed disinfectants. As a control, we used a Lamador seed disinfectant $(0.21 / t)$, as well as new seed disinfectant: Scenic Combi $(1.51 / t)$, Baritone $(1.5 \mathrm{l} / \mathrm{t})+$ Nuprid $(0.6 \mathrm{l} / \mathrm{t})$, Redigo (0.55 $1 / t)+\operatorname{Nuprid}(0.61 / t)$. Positive annual total cost savings of 119 rubles per 1 ton of produced grain was shown by the variant of seed treatment with a combination of Aquamix ST + Lamador. Other variants with the same agronomical efficiency, but with more expensive new seed disinfectants, turned out to be unprofitable. When evaluating the methods of foliar dressing, the highest yield of winter wheat at $3.98 \mathrm{t} / \mathrm{ha}$ was obtained using the innovative method of functional foliar diagnostics. The best indicators of the economic efficiency of the improved technology for the production of winter wheat were established in the variant of seed treatment Aquamix ST + Lamador with the application of foliar dressing using an innovative method. At the same time, the annual savings in total costs amounted to 476 rubles/t, which is 1.34 times higher than the variant with standard fertilizing with complex fertilizer Aquarin 5.
\end{abstract}

\section{Introduction}

Winter wheat is the most widespread grain crop, which is a raw material for the production of basic food products for $35 \%$ of the world's population [1]. Its grain is high in protein, fat and carbohydrates. Wheat flour is used in bakery and confectionery. Waste from the milling and alcohol industry, as well as straw, is used for animal feed. In Central Chernozem Region, winter wheat occupies 1,130 thousand hectares, which is $18.2 \%$ of the region's arable land.

High efficiency of modern intensive technologies for winter wheat production is impossible without mineral fertilizers, which make a significant contribution to the global provision of humanity with food [2]. Their scientifically substantiated rates increase both yield and grain quality [3].

Fertilizers should contain mobile forms of not only macro - (NPK), but also micronutrients. In contrast to NPK, the need of plants for microelements is satisfied by an amount that is tens and hundreds of thousands of times smaller. However, a small amount of micronutrient fertilizer that is not received can cause diseases of plants, a significant decrease in their productivity and even death.
The use of NPK alone for decades caused micronutrient deficiencies and soil deterioration [4]. Their balanced application with macronutrients increases crop yields and increases the efficiency of NPK use [3], [5].

The effectiveness of micronutrient fertilizers depends on the method of delivery to plants. Applying them to the soil by root dressing is ineffective, since most of the nutrients are bound by the soil-absorbing complex into an immobile form and is inaccessible to plants. The loss of micronutrient fertilizers can reach $120-80 \%$ [3]. But fertilizer is an ingredient to feed crops, not soil [6]. Therefore, the need of plants for micronutrient fertilizers is satisfied with an economical pre-sowing application on seeds combined with seed dressing and foliar dressing [7].

Micronutrient fertilization on seeds gives them an impulse for early plant viability [3]. With foliar dressing, small rates of preparations dissolved in water are absorbed by the leaves well, as a result of which the efficiency of micronutrient fertilizers reaches $90 \%$.

The principle of adaptability of the use of fertilizers is directly related to the necessity of assessing the true needs of crops grown, both in macro- and microelements [8], [9].

Macronutrients are traditionally applied to the soil based on soil diagnostics. Rates of micronutrient fertilizers applied to seeds are set according to the 
recommendations of their manufacturers. The subsequent adjustment and optimization of plant nutrition is carried out according to the data of foliar diagnostics, eliminating the deficiency of nutrients during the growing season with foliar dressings necessary for the formation of a high quality grain yield [10] - [12].

Foliar diagnostics are divided into visual, chemical and functional diagnostics.

The advantage of visual foliar diagnostics is its simplicity. However, when the method is used, most of the symptoms of nutritional deficiency are manifested for their groups, in which it is very difficult to identify a really deficient element. In addition, only an experienced researcher can obtain objective data when using the method.

Chemical diagnostics are based on a static analysis of the composition of plant tissues. But in certain vegetation phases plants, regardless of the composition of the tissues, require a different amount of nutrients. This necessitates a controlled supply of nutrients throughout the entire life cycle of the plant organism, i.e. the fact of the presence of nutrients in tissues does not reflect the current demand of plants for them.

Fundamentally new is the method of functional foliardiagnostics proposed by A.S. Pleshkov and B.A. Yagodin, which, according to the reaction of living plants, allows us to estimate their true need for nutrients [13]. When using the method, it is not the content of nutrients that is assessed, but the need of plants for them, since it has been proven that plants have all the properties of an organized living being [14].

The method is based on the fundamental properties of the existence of life on the Earth - the relationship of the photochemical activity of chloroplasts of living plants with their need for nutrients.

Chloroplasts are a unique factory for the synthesis of organic matter. The photochemical activity of their suspension with the addition of some nutrient changes in proportion to the supply of plants with this element. The deficiency of the element is determined by the increase, and the excess - by the decrease in photochemical activity in comparison with the control. The degree of change in photochemical activity due to the presence of a test element in the nutrient medium makes it possible to judge of the magnitude of its need or excess.

But the method of A.S. Pleshkov and B.A. Yagodin is inherent in a serious disadvantage. The diagnosis of each of the nutrients is carried out separately from other components of the nutrient medium, which makes it impossible to assess their mutual influence and, accordingly, the optimal ratio, the observance of which has a decisive effect on the productivity of plants and the quality of the yield.

An important prerequisite for minimizing the cost of fertilizer resources was the further improvement of functional diagnostics in order to take into account the synergy of interaction of nutrients in plants when diagnosing a need. The essence of the innovation consists in assessing the need not individually for each nutrient, but for their specially selected nutrient mixture [15]. The effectiveness of the innovation is confirmed by state tests using the Aquadonis device [16].

\section{The purpose of the research was}

to improve the technology for the production of winter wheat in Central Chernozem Region (CChR) by increasing the efficiency of the use of modern micronutrient fertilizers in conjunction with seed disinfectants and foliar applications. To achieve this goal, it was envisaged to solve the following tasks:

- determine the most effective combination of standard micronutrient fertilizer applied to seeds with the type of a seed disinfectant;

- to evaluate the effectiveness of foliar dressing of a crop with a nutrient mixture formed by an innovative method of functional foliar diagnostics using various variants for seed treatment, taking into account the synergy of interaction between nutrients.

\section{Conditions, materials and methods}

An improved technology for the production of winter wheat was developed by a representative of Kursk FARC with the participation of specialists of Central Chernozem Machine Testing Station and implemented in a three-year field experiment (2017-2020). The basic agricultural techniques of the improved technology in the experiment corresponded to the regional technology.

The soil of the experiment was slightly leached medium loamy chernozem with a humus content of $5.0 \%$. In its structure, the predominant fraction is up to $10 \mathrm{~mm}$ $85.1 \%$. Salt extract $\mathrm{pH}_{\mathrm{KCl}}=5.1$. The content of alkaline hydrolysable nitrogen is 12.0 , mobile phosphorus - 14.2 and exchangeable potassium - $10.7 \mathrm{mg}$ per $100 \mathrm{~g}$ of soil. The relief is even.

The winter wheat variety "Augustina" was bred by the Scientific and Practical Center of the National Academy of Sciences of Belarus. The seed purity was $99.2 \%$, the germination rate was $93.8 \%$, the sowing capacity was $83.1 \%$. The weight of 1000 seeds was $40.7 \mathrm{~g}$.

When determining the combination of micronutrient fertilizer applied to seeds with a seed disinfectant, we used the standard domestic preparation Aquamix ST at a rate of $100 \mathrm{~g}$ per 1 ton of seeds. The preparation is produced by the Buisk Chemical Plant (Kostroma Region). The active ingredient of the micronutrient fertilizer is as this, $\%: N=1.55 ; \mathrm{P}_{2} \mathrm{O}_{5}=5.0 ; \mathrm{K}_{2} \mathrm{O}=1.55 ; \mathrm{Fe}(\mathrm{DTPA})=$ $1.74 ; \mathrm{Fe}(\mathrm{EDTA})=2.1 ; \mathrm{Mn}(\mathrm{DTPA})=2.57 ; \mathrm{Zn}(\mathrm{DTPA})$ $=0.53 ; C u(\mathrm{DTPA})=0.53 ; C a(\mathrm{DTPA})=2.57 ; B=0.52$; $M o=0.13$.

In the research seed disinfectants manufactured by Bayer company, Germany, which are widely represented at the Russian market, were used. The agronomical efficiency of seed treatment with combinations of micronutrient fertilizers with seed disinfectants was assessed in a one-factor experiment carried out in four replications (Table 1). 
Table 1. Design of a one-factor experiment on the effect of seed treatment with a combination of micronutrient fertilization with seed disinfectants on winter wheat yield

\begin{tabular}{|c|c|c|c|c|c|c|}
\hline \multirow[b]{3}{*}{ Variants } & \multirow[b]{3}{*}{ Factor } & \multicolumn{5}{|c|}{ Productivity, $\mathrm{t} / \mathrm{ha}$} \\
\hline & & \multicolumn{3}{|c|}{ Years of testing } & \multirow[b]{2}{*}{$\begin{array}{l}\text { Average } \\
\text { options }\end{array}$} & \multirow{2}{*}{$\begin{array}{l}\text { Difference } \\
\text { between the } \\
\text { average values of } \\
\text { the controls } \\
\text { and variants }\end{array}$} \\
\hline & & 2018 & 2019 & 2020 & & \\
\hline $\begin{array}{c}1 \\
\text { (control) }\end{array}$ & Lamador & 2.06 & 3.07 & 5.30 & 3.48 & 0 \\
\hline 2 & $\begin{array}{l}\text { Aquamix ST + } \\
\text { Lamador }\end{array}$ & 2.12 & 3.17 & 5.47 & 3.59 & 0.11 \\
\hline 3 & $\begin{array}{c}\text { Aquamix ST }+ \\
\text { Scenic Combi }\end{array}$ & 2.12 & 3.21 & 5.49 & 3.60 & 0.13 \\
\hline 4 & $\begin{array}{c}\text { Aquamix ST }+ \\
\text { Baritone }+ \text { Nuprid }\end{array}$ & 2.14 & 3.19 & 5.47 & 3.60 & 0.12 \\
\hline \multirow[t]{2}{*}{5} & $\begin{array}{c}\text { Aquamix ST + } \\
\text { Redigo + Nuprid }\end{array}$ & 2.14 & 3.21 & 5.49 & 3.61 & 0.14 \\
\hline & $\begin{array}{c}\text { Average of the } \\
\text { replications }\end{array}$ & 2.12 & 3.17 & 5.44 & $\begin{array}{c}\text { General } \\
\text { average } 3.58 \\
\end{array}$ & \\
\hline \multicolumn{2}{|c|}{$\mathrm{LSD}_{05}$} & \multicolumn{5}{|c|}{0.045} \\
\hline
\end{tabular}

Microfertilizers were not applied to the seeds of control variant 1 . They were treated with the Lamador seed disinfectant, which showed itself positively for a long time in the agriculture of Central Chernozem Region. In variants $2-5$, the seeds were treated with micronutrient fertilizer Aquamix ST in combination with new seed disinfectants, as well as with Lamador seed disinfectant.
The effectiveness of foliar dressing of winter wheat with a nutrient mixture formed by an innovative method of foliar functional diagnostics was assessed in various variants for seed treatment in a two-factor $3 \times 4$ experiment performed in four randomized replications (Table 2).

Table 2. Experiment factors

\begin{tabular}{|l|l|}
\hline Foliar dressing factor & Seed treatment factor \\
\hline 0 - without foliar dressing & 0 - Lamador $(0.2 \mathrm{l} / \mathrm{t})+$ Aquamix ST $(100 \mathrm{~g} / \mathrm{t})$ \\
\hline $\begin{array}{l}1 \text { - two foliar dressings with micronutrient fertilizer Aquarin 5, } \\
3 \mathrm{~kg} / \mathrm{ha}\end{array}$ & $1-$ Scenic Combi $(1.5 \mathrm{l} / \mathrm{t})+$ Aquamix ST $(100 \mathrm{~g} / \mathrm{t})$ \\
\hline $\begin{array}{l}2-\text { two foliar dressings with a nutrient mixture of fertilizers in } \\
\text { the nomenclature and rates according to the data of the } \\
\text { Aquadonis laboratory }\end{array}$ & $\begin{array}{l}2-\text { Baritone }(1.5 \mathrm{l} / \mathrm{t})+\text { Nuprid }(0.6 \mathrm{l} / \mathrm{t})+\text { Aquamix } \\
\text { ST }(100 \mathrm{~g} / \mathrm{t})\end{array}$ \\
\hline & $\begin{array}{l}3-\text { Redigo }(0.55 \mathrm{l} / \mathrm{t})+\text { Nuprid }(0.6 \mathrm{l} / \mathrm{t})+\text { Aquamix } \\
\text { ST }(100 \mathrm{~g} / \mathrm{t})\end{array}$ \\
\hline
\end{tabular}

Table 3. Design of a two-factor experiment $3 \times 4$ on the effect of foliar dressings and seed treatments with micronutrient fertilizers in conjunction with seed disinfectants on the yield of winter wheat grain

\begin{tabular}{|c|c|c|c|c|c|c|}
\hline \multirow{3}{*}{ Variants } & \multirow{2}{*}{\multicolumn{2}{|c|}{ Factors }} & \multicolumn{4}{|c|}{ Yield, t/ha } \\
\hline & & & & s of te & & \\
\hline & foliar dressing & seed treatment & 2018 & 2019 & 2020 & variants \\
\hline 1 & \multirow{4}{*}{0} & 0 & 2.12 & 3.17 & 5.47 & 3.59 \\
\hline 2 & & 1 & 2.12 & 3.21 & 5.49 & 3.60 \\
\hline 3 & & 2 & 2.14 & 3.19 & 5.47 & 3.60 \\
\hline 4 & & 3 & 2.14 & 3.21 & 5.49 & 3.61 \\
\hline 5 & \multirow{4}{*}{1} & 0 & 2.25 & 3.39 & 5.73 & 3.79 \\
\hline 6 & & 1 & 2.24 & 3.38 & 5.61 & 3.75 \\
\hline 7 & & 2 & 2.25 & 3.41 & 5.81 & 3.82 \\
\hline 8 & & 3 & 2.26 & 3.39 & 5.76 & 3.80 \\
\hline 9 & 2 & 0 & 2.33 & 3.50 & 6.12 & 3.98 \\
\hline
\end{tabular}




\begin{tabular}{|l|l|l|l|l|l|l|}
\hline \multirow{2}{*}{10} & 1 & 2.33 & 3.49 & 6.11 & 3.97 \\
\hline \multirow{2}{*}{11} & 2 & 2.34 & 3.50 & 6.09 & 3.97 \\
\cline { 3 - 6 } & & 3 & 2.34 & 3.52 & 6.12 & 3.99 \\
\hline \multicolumn{2}{|c|}{ LSD $_{05}$} & \multicolumn{5}{|c|}{0.087} \\
\hline
\end{tabular}

Foliar dressing in the variants of the experiment was carried out 2 times by spraying crops in the phases of tillering and heading of plants. There is also a variant without foliar dressing. The experiment design is presented in Table 3.

For comparison, standard foliar dressing was performed with the domestic complex water-soluble micronutrient fertilizer Aquarin 5, produced by the Buisk chemical plant. Micronutrient fertilizer was applied at a rate of $3 \mathrm{~kg} / \mathrm{ha}$ in one foliar dressing. Its active ingredient is as follows, \%: $\mathrm{N}=18.0 ; \mathrm{P}_{2} \mathrm{O}_{5}=18.0 ; \mathrm{K}_{2} \mathrm{O}=18.0 ; \mathrm{MgO}$ $=2.0 ; \mathrm{S}=1.5 ; \mathrm{Fe}(\mathrm{DTPA})=0.054 ; \mathrm{Zn}(\mathrm{EDTA})=0.014$; $C u($ EDTA $)=0.01 ; M n($ EDTA $)=0.042 ; M o=0.004 ; B$ $=0.02$.

The synergy of interaction between the nutrients was formed by varying their ratio in the process of diagnostic actions. For this, multivariant non-repeating mixtures of nutrients were tested by the method of mathematical planning of the experiment based on the matrix of a fractional replica. Then, using digital technologies, we formalized a model of interconnected factor space [15].

The calculation of economic indicators was carried out in accordance with GOST 34393-2018 and STO AIST 1.3-2010. In this case, the following was taken into account.

Technological operations for all the variants are the same, as a result of which the composition and cost of the machine and tractor fleet, i.e. capital investments are the same. In all the variants mineral fertilizer diammophos and ammonium nitrate were applied as the main one, and double spraying of crops with a solution of micronutrient fertilizers in a tank mixture with pesticides was used. The treatment of crops in all the variants was also the same with the herbicide Asterix, the fungicide Falcon, and the insecticide Borey.

The prices for the equipment used are taken according to the data of the manufacturers. The price of seeds and grain is presented by the accounting department of the Central Chernozem Machine Testing Station. To calculate the economic indicators, we used the materials of the operational and technological assessment of machines and the regulatory and reference material. The tested variants of the technology differed by a variable factor.

\section{Results and discussion}

In the experiment on the effect of seed treatment with a combination of micronutrient fertilizer and seed disinfectants (Table 1) on the yield of winter wheat, the following was established. Only the increase in grain yield was significant for the variants of seed treatment with Aquamix ST micronutrient fertilizer combined with seed disinfectants. The increase was 0.11-0.14 t/ha (3.1$3.8 \%$ ). The difference between the average variants did not exceed $0.03 \mathrm{t} / \mathrm{ha}$ and was insignificant, since it was less than $\mathrm{LSD}_{05}=0.045 \mathrm{t} / \mathrm{ha}$. Consequently, the agronomical efficiency of any of the tested disinfectants increases approximately equally in comparison with the control only when it is used in combination with Aquamix CT micronutrient fertilizer.

According to the economic assessment, variants 1-5 differ insignificantly in terms of production costs, labor costs, the cost of grain and the productivity of machine operators (Table 4).

Table 4. Agroeconomic indicators of winter wheat cultivation technology variants in terms of the effect on the yield of seed treatment with a combination of micronutrient fertilizers and seed disinfectants, average for 2018-2020

\begin{tabular}{|c|c|c|c|c|c|}
\hline \multirow{2}{*}{ Indicators } & \multicolumn{5}{|c|}{ Technology variants } \\
\cline { 2 - 6 } & 1 & 2 & 3 & 4 & 5 \\
\hline Grain yield, t/ha & 3.48 & 3.59 & 3.60 & 3.60 & 3.61 \\
\hline Production costs, ruble/t & 4257 & 4180 & 4771 & 4603 & 4513 \\
\hline Labor costs, man-h/t & 1.03 & 1.01 & 1.01 & 1.01 & 1.01 \\
\hline Cost of grain, ruble/t & 7006 & 6875 & 7464 & 7287 & 7196 \\
\hline Labor productivity of a machine operator, rubles/person & 1103 & 1128 & 1130 & 1130 & 1132 \\
\hline Annual savings in total cash costs, ruble/t & - & 119 & -384 & -244 & -162 \\
\hline
\end{tabular}

However, the combination of new seed disinfectants with micronutrient fertilizers is much more expensive than the Aquamix ST + Lamador variant. Therefore, only the Lamador + Aquamix ST variant showed positive annual savings in total costs of 119 rubles / t. Other tested variants for seed treatment in comparison with the control turned out to be unprofitable.

A comprehensive assessment of the effectiveness of the use of micronutrient fertilizers on winter wheat was performed, both on seed treatment together with seed disinfectants, and foliar dressings (Table 5).

Table 5. Agroeconomic indicators of improved technology variants of winter wheat cultivation, average for 2018-2020 


\begin{tabular}{|c|c|c|c|c|c|c|c|c|c|}
\hline \multirow[t]{3}{*}{ Indicators } & $\begin{array}{l}\text { Without } \\
\text { foliar } \\
\text { dressings }\end{array}$ & \multicolumn{4}{|c|}{$\begin{array}{l}\text { Two foliar dressings with } \\
\text { micronutrient fertilizer } \\
\text { Aquarin } 5,3 \mathrm{~kg} / \mathrm{ha} \text { each }\end{array}$} & \multicolumn{4}{|c|}{$\begin{array}{l}\text { Two foliar dressings with a nutrient mixture } \\
\text { of fertilizers in the nomenclature and rates } \\
\text { according to the Aquadonis laboratory }\end{array}$} \\
\hline & \multicolumn{9}{|c|}{ Technology variants } \\
\hline & 1 & 5 & 6 & 7 & 8 & 9 & 10 & 11 & 12 \\
\hline Grain yield, t/ha & 3.59 & 3.79 & 3.75 & 3.82 & 3.80 & 3.98 & 3.97 & 3.97 & 3.99 \\
\hline $\begin{array}{c}\text { Production costs, } \\
\text { ruble/t }\end{array}$ & 4180 & 4090 & 4679 & 4484 & 4407 & 4131 & 4672 & 4526 & 4436 \\
\hline $\begin{array}{c}\text { Labor costs, man- } \\
\mathrm{h} / \mathrm{t}\end{array}$ & 1.01 & 0.95 & 0.95 & 0.94 & 0.94 & 0.91 & 0.91 & 0.91 & 0.90 \\
\hline $\begin{array}{c}\text { Cost of grain, } \\
\text { ruble } / \mathrm{t}\end{array}$ & 6,875 & 6,606 & 7,214 & 6,985 & 6,914 & 6,542 & 7,087 & 6,936 & 6,838 \\
\hline $\begin{array}{l}\text { Labor productivity } \\
\text { of a machine } \\
\text { operator, } \\
\text { ruble/person }\end{array}$ & 1,128 & 1,201 & 1,186 & 1,212 & 1,206 & 1,265 & 1,263 & 1,262 & 1,268 \\
\hline $\begin{array}{l}\text { Annual savings in } \\
\text { total cash costs, } \\
\text { ruble/t }\end{array}$ & 119 & 355 & -195 & 37 & 86 & 476 & 0,46 & 124 & 216 \\
\hline
\end{tabular}

Statistical analysis according to Fisher's criterion established a significant effect of the factor of foliar dressing on the grain yield of the crop: $\mathrm{F}_{\mathrm{f}}>\mathrm{F}_{05}, \mathrm{LSD}_{05}=$ $0.083 \mathrm{t} / \mathrm{ha}$.

The use of foliar dressings (variants 5-12) made it possible to increase the yield of the grain of winter wheat of the 3rd class, on the average, according to the experiment, by $0.28 \mathrm{t} / \mathrm{ha}$, which is $7.9 \%$.

The block of four variants (9-12) of the technology with foliar dressing with a nutrient mixture of micronutrient fertilizers, formed in an innovative way, showed the greatest efficiency. The average grain yield of winter wheat in these variants was $3.98 \mathrm{t} / \mathrm{ha}$, which exceeded by $0.38 \mathrm{t} / \mathrm{ha}(10.5 \%)$ the variants without foliar dressing, and by 0.19 t/ha $(5.0 \%)$ the variants with standard foliar fertilization with complex fertilizer Aquarin 5.

In blocks differing in foliar dressing, the best agroeconomic indicators are expected in variants 1,5 , and 9 with seed treatment with Aquamix ST + Lamador. In terms of grain yield, variant 9 exceeded variant 5 by $5.0 \%$ and variant 1 by $10.9 \%$.

By comparing the economic indicators of foliar dressing methods in variants 1,5 and 9 , approximately the same labor costs and cost per 1 ton of produced grain were established. But at the same time, according to the annual savings in total costs, the method of variant 9 (476 rubles/t) exceeded variant 51.34 times and variant 14.0 times. This is due to an increase in crop yield, as well as lower costs for micronutrient fertilizers due to optimization of their use, which along the way ensured an ecological effect in the form of a gentle chemical effect on the environment [17].

\section{Conclusions}

The research has established the best indicators of the economic efficiency of winter wheat production in Central Chernozem Region in the variant of combining seed treatments with Aquamix ST microfertilizer and
Lamador seed disinfectant, as well as performing foliar fertilization of the crop with a micronutrient mixture formed in an innovative way that takes into account the synergy of interaction between the nutrients. At the same time, annual savings in total costs of 476 rubles/t was obtained, which was 1.34 times higher than the variant with standard fertilizing with complex fertilizer Aquarin 5. Indicators of economic and environmental efficiency of improving agricultural technology indicate the prospect of its use by agricultural entities in Central Chernozem Region.

\section{References}

1. A. Rehman, M. Farooq, K.H.M. Siddique, et al. Plant and Soil 422 283-315 (2018)

2. Г.Н. Черкасов. Научн.-агрономич. журн., 2, 5-7 (2011)

3. P.S. Bindraban, C. Dimkpa, L. Nagarajan, et al. Biology and Fertility of Soils, 51, 8, 897-911 (2015)

4. Bindraban P.S, van der Velde M., Ye L., et al. Curr Opin Environ Sust, 4, 478-488 (2012)

5. W. Ding, X. Xu, P. He, et al. Field Crops Research, 227, 11-18 (2018)

6. P.J.A. Withers, R. Sylvester-Bradley, D.L. Jones, et al. Environ Sci Technol, 48, 6523-6530 (2014)

7. I. Cakmak, A. Yazici, Y. Tutus, et al. Plant and Soil. 418, 1-2, 319-335 (2017)

8. А.Б. Хорошкин. Способы повышения эффективности минерального питания сельскохозяйственных культур (2011)

9. C.M. Monreal, M. Derosa, S.C. Mallubhotla, et al. Biology and Fertility of Soils, 52, 3, 423-437 (2016)

10. Н.Н. Беляев, Е.А. Дубинкина. Земледелие, 6, 4547 (2013)

11. В.И. Цыганков. Земледелие, 6, 21 (2007)

12. В.И. Лазарев, И.А. Золотарева, О.М. Шершнева. Земледелие, 2, 23-24 (2014)

13. А.С. Плешков, Б.А. Ягодин. Авт. свид. USSR 952168, 31 (1982) 
14. И.И. Гуреев. Пат. RU 2541310, 4 (2015)

15. А.А. Лихова, М.Н. Жердев. Информ. издание ФГБНУ «Росинформагротех» (2020)

16. D. Wang, J. Zuo, H. Zhou, et al. Agriculture, Ecosystems \& Environment, 301, 106970 (2020) 